\title{
Kepastian Hukum Dalam Pembuatan Surat Kuasa Membebankan Hak Tanggungan
}

\author{
Ketut Nurcahya Gita ${ }^{1}$, I Made Udiana ${ }^{2}$
}

${ }^{1}$ Fakultas Hukum Universitas Udayana, E-mail: ketutnurcahyagita@gmail.com

2 Fakultas Hukum Universitas Udayana, E-mail: made_udiana@unud.ac.id

\begin{tabular}{l}
\hline Info Artikel \\
\hline Masuk: 4 Februari 2021 \\
Diterima:10 Mei 2021 \\
Terbit: 1 Juli 2021 \\
Keywords: \\
Power of Attorney, Notary, \\
Authentic Deed. \\
\\
\\
\\
m \\
Kotut Nurcahya Gita, \\
k-mail: \\
10.24843/AC.2021.v06.i02.p05 \\
Kata kunci: \\
Surat Kuasa, Notaris, Akta \\
Autentik. \\
\end{tabular}

\begin{abstract}
The purpose of this writing is to find out about legal certainty and comparison of power of attorney to impose mortgage rights stipulated in the Notary Position Law No.2 of 2014 with the form stipulated by the Head of Land Agency Regulation No.8 of 2012. This research uses normative legal research methods. The results of this study show that the comparison of authentic deeds according to the Law of Notary Position No.2 of 2014 and the Regulation of the Head of the Land Agency No.8 of 2012 regarding the creation of a power of attorney to impose mortgage rights made before a notary there are differences in the head and end of the deed. The form of power of attorney imposes a security right issued by the State Land Agency of the Republic of Indonesia which is different and not in accordance with the provisions stipulated in the Law of Notary Position No. 2 of 2014. Second, the legal certainty of the power of attorney imposes a security right made by a Notary by following format of the Head of the Land Agency Regulation No.8 of 2012, the deed cannot provide legal certainty. The deed will be degraded into a letter under the hand, so that it cannot be used as a basis in making the deed of mortgage imposition, however, the Notary is given the right to add deficiencies to the blank so that it remains an authentic deed.
\end{abstract}

\section{Abstrak}

Tujuan penulisan ini untuk mengetahui mengenai kepastian hukum serta perbandingan surat kuasa membebankan hak tanggungan yang diatur dalam Undang-Undang Jabatan Notaris No.2 Tahun 2014 dengan Blanko yang ditentukan Peraturan Kepala Badan Pertanahan No.8 Tahun 2012. Penelitian ini menggunakan metode penelitian hukum normatif. Hasil penelitian ini menunjukan perbandingan akta autentik menurut Undang-Undang Jabatan Notaris No.2 Tahun 2014 dan Peraturan Kepala Badan Pertanahan No.8 Tahun 2012 dalam mengenai pembuatan surat kuasa membebankan hak tanggungan yang dibuat dihadapan Notaris terdapat perbedaan pada kepala dan akhir akta. Blanko surat kuasa membebankan hak tanggungan yang diterbitkan Badan Pertanahan NegaraRepublik Indonesia berbeda dan tidak sesuai dengan ketentuan yang telah ditetapkan dalam Undang-Undang Jabatan Notaris No.2 Tahun 2014. Kedua, kepastian hukum surat kuasa 
membebankan hak tanggungan yang dibuatoleh Notaris dengan mengikuti format Peraturan Kepala Badan Pertanahan No.8 Tahun 2012 maka akta tersebut tidak dapat memberikan kepastian hukum. Akta tersebutakan terdegradasi menjadi surat dibawahtangan, sehingga tidak bisa dijadikan dasar dalam pembuatan akta pembebanan hak tanggungan, akan tetapi Notaris diberikan hak untuk menambahkan kekurangan pada blangko tersebut agar tetap menjadi akta autentik.

\section{Pendahuluan}

Bank memberi dampak yang sangat besar dan memiliki andil dalam pergerakan perekonominan. Bank sebagai lembaga simpan pinjam yang memberikan produkproduk yang dibutuhkan oleh masyarakat. ${ }^{1}$ Salah satu produk perbankan adalah menyalurkan kredit dan ini membantu usaha bagi masyarakat. ${ }^{2}$

Undang-Undang Nomor 7 Tahun 1992 dan perubahannya Undang-Undang Nomor 10 Tahun 1998 tentang Perbankan (selanjut disebut UUPerbankan) dalam Pasal 1 ayat (11) menentukan bahwa:

"Kredit adalah penyediaan uang atau tagihan yang dapat dipersamakan dengan itu, berdasarkan persetujuan atau kesepakatan pinjam-meminjam antara Bank dengan pihak lain yang mewajibkan pihak peminjam untuk melunasi hutangnya setelah jangka waktu tertentu dengan jumlah bunga, imbalan atau pembagian hasil keuntungan"

Menurut O.P Simorangkir, kredit adalah pemberian prestasi berupa uang atau barang yang kemudian mendapatkan balasan prestasi juga namun akan didapatkan pada waktu mendatang. ${ }^{3}$ Kredit adalah adanya kepercayaan. Kredit merupakan bentuk hubungan antara kreditur/pemberi kredit dan debitur/penerima kredit, dimana keduanya saling mendapatkan untung dan menanggung resiko. Kredit adalah perjanjian yang didasarkan adanya rasa percaya, resiko dan juga keuntungan. Perjanjian kredit merupakan perjanjian pendahulu (panctum de contrahendo), sehingga perjanjian ini dibuat sebelum dibuatnya perjanjian kredit. ${ }^{4}$ Perjanjian kredit yang merupakan bentuk kesepakatan antara debitur/penerima kredit dengan kreditur/pemberi kredit yang diberikan oleh lembaga perbankan memiliki fungsi, yang merupakan upaya preventif yaitu sebagai perjanjian utama, alat pembuktian,

1 Tambunan, M. R., \& Nasution, I. G. S. (2013). Analisis faktor-faktor yang mempengaruhi keputusan nasabah menabung di Bank BCA kota Medan (Studi kasus etnis Cina). Jurnal Ekonomi dan Keuangan, 1(3), 14727. h.193.

2 Rusdianto, H., \& Ibrahim, C. (2016). Pengaruh Produk Bank Syariah Terhadap Minat Menabung Dengan Persepsi Masyarakat Sebagai Variabel Moderating Di Pati. Equilibrium: Jurnal Ekonomi Syariah, 4(1), h.44. DOI: 10.21043/ equilibrium.v4i1.1837

3 Simorangkir, O.P., 1998, Seluk Beluk Bank Komersial, Persadai Indonesia, Jakarta, h.91

${ }_{4}$ Pakel, Y. (2018). Kedudukan Bank Sebagai Kreditor Separatis Dalam Pengurusan Dan Pemberesan Harta Pailit. Al-Amwal: Journal of Islamic Economic Law, 3(1), h.63. DOI: https://doi.org/10.24256/alw.v3i1.200 
dan sebagai alat untuk melakukan pemantauan kredit. ${ }^{5}$

Perjanjian kredit antara bank dan nasabah menimbulkan hak dan kewajiban, dimana kewajiban nasabah adalah memberikan jaminan atas pinjaman yang diberikan oleh bank. Adapun yang menjadi obyek jaminan kredit bank itu haruslah sesuai dengan aturan perbankan tersebut, jaminan harus dapat menjadi alat pelunas utang jika terjadi wanprestasi. ${ }^{6}$ Pentingnya jenis objek jaminan karena berkaitan dengan perlindungan dan kepastian hukum bagi semua pihak yang berkepentingan. Sudah semestinya bank mendapatkan perlindungan hukum dari jaminan tersebut. Biasanya jaminan pada bank adalah sertifikat hak milik atas tanah, karena itu jaminan tersebut wajib didaftarkan sesuai dengan Pasal 4 Undang-Undang Nomor 4 Tahun 1996 tentang Hak Tanggungan (selanjut disebut UUHT).

Pasal 10 angka (1) UUHT, menyebutkan: “Pemberian Hak Tanggungan didahului dengan janji untuk memberikan Hak Tanggungan sebagai jaminan pelunasan utang tertentu, yang dituangkan di dalam dan merupakan bagian yang tidak terpisahkan dari perjanjian hutang piutang yang bersangkutan dan perjanjian lain yang menimbulkan utang tersebut." Hak Tanggungan (selanjutnya disebut HT) adalah pembebanan pada sebuah jaminan hak atas tanah dalam suatu perjanjian peminjaman uangada bank. Pasal 13 UUHT menentukan "tahap pemberian hak tanggungan ini dilakukan dengan dibuatnya Akta Pemberian Hak Tanggungan oleh Pejabat Pembuat Akta Tanah."

Akta autentik dalam pembuatannya, maka penghadap harus berhadapan dengan PPAT, dan pada pengajuan HT juga harus hadir, namun jika yang bersangkutan tidak dapat hadir maka penghadap harus membuat surat kuasa membebankan hak tanggungan (selanjut disebut SKMHT). Berdasarkan Pasal 15 (1) UUHT: "surat kuasa pembebanan Hak Tanggungan wajib dibuat dengan akta Notaris atau akta Pejabat Pembuat Akta Tanah" (selanjut disebut PPAT). Menurut ketentuan tersebut, maka Notaris juga memiliki kewenangan membuat SKMHT.

Untuk dapat menentukan SKMHT dibuat oleh PPAT atau Notaris, maka dapat dilihat dari wilayah dimana letak objek HT tersebut, jika objek HT berada di kedudukan kerja PPAT, maka SKMHT dibuat oleh PPAT, sedangkan jika diluar kedudukan kerja, maka SKMHT dibuat oleh Notaris. PPAT dalam menjalankan jabatannya tunduk terhadap aturan-aturan Kepala BPN RI, sedangkan Notaris, dalam menjalankan jabatannya tunduk pada Peraturan Jabatan Notaris.

Pasal 1 (7) Undang-Undang Jabatan Notaris No.2 Tahun 2014 (selanjut disebut UUJN) menegaskan, bahwa "akta notaris adalah akta autentik yang dibuat oleh atau dihadapan Notaris menurut bentuk dan tata cara yang ditetapkan dalam UndangUndang ini." Keautentikan suatu akta adalah isinya harus sesuai dengan apa yang ditentukan oleh undang-undang dan bukan hanya karena dibuat dihadapan pejabat

\footnotetext{
${ }^{5}$ Setiono, G. C. (2018). Jaminan kebendaan dalam proses perjanjian kredit perbankan (tinjauan yuridis terhadap jaminan benda bergerak tidak berwujud). Transparansi Hukum, 1(1), h.7. DOI: http:// dx.doi.org/10.30737/transph.v1i1.159

${ }^{6}$ Yusuf, Rifki \& Maryanto. (2018). Peran Notaris Dalam Penggunaan Akta SKMHT Yang Tidak Diikuti APHT Terhadap Debitor Wanprestasi Terkait Pemberian Fasilitas Kredit Pemilikan Rumah Subsidi (Studi Kasus di Bank Tabungan Negara Pekalongan). Jurnal Akta, 5(1), h.282.
} 
saja, sehingga jika akta dibuat oleh Notaris tetapi bentuknya tidak mengikuti apa yang di tegaskan dalam undang-undang maka tidak dapat dikatakan akta autentik, namun akan terdegradasi menjadi akta dibawahtangan. Dikatakan terdegradasi menjadi akta dibawahtangan karena tidak sesuai dengan ketentuan Pasal 1868 KUHPer, menjelaskan akta autentik ialah "suatu akta yang didalam bentuk yang ditentukan

oleh undang-undang, dibuat oleh atau dihadapan pegawai-pegawai umum yang berkuasa untuk itu ditempat dimana akta dibuatnya."

SKMHT agar dapat dikatakan akta autentik, maka Notaris harus mengikuti apa yang diatur dalam UUJN pada Pasal 38, bahwa:

(1) "Setiap akta notaris terdiri atas:

a. Awal akta dan kepala akta

b. Badan akta; dan

c. Akhir dan penutup akta"

(2) "Awal akta dan kepala akta memuat:

a. Judul akta

b. Nomor akta

c. Jam, hari, tanggal, bulan dan tahun; dan

d. Nama"

Notaris harus tunduk terhadap UUJN, sesuai dengan Pasal 38 UUJN yang akta autentik, apabila SKMHT tidak berdasarkan pasal tersebut, maka SKMHT yang dibuat dapat dikatakan bukan akta autentik.

Berdasarkan uraian latar belakang tersebut, maka terdapat dua rumusan masalah yang akan dianalisa, yaitu mengenai bagaimana perbandingan surat kuasa membebankan hak tanggungan (SKMHT) yang diatur dalam UUJN dengan Blanko yang ditentukan Peraturan Kepala Badan Pertanahan No.8 Tahun 2012? Serta bagaimana Kepastian hukum surat kuasa membebakan hak tanggungan (SKMHT) yang dibuat dihadapan Notaris dengan mengikuti blanko Peraturan Kepala Badan Pertanahan No.8 Tahun 2012?

Tujuan penulisan ini yang pertama untuk mengetahui tentang perbandingan surat kuasa membebankan hak tanggungan (SKMHT) yang diatur dalam Undang-Undang Jabatan Notaris No.2 Tahun 2014 dengan Blanko yang ditentukan Peraturan Kepala Badan Pertanahan No.8 Tahun 2012. Kedua, untuk mengetahui dan menganalisa mengenai kepastian hukum surat kuasa membebakan hak tanggungan (SKMHT) yang dibuat dihadapan Notaris dengan mengikuti blanko Peraturan Kepala Badan Pertanahan No.8 Tahun 2012.

Adapun penelitian dahulu yang memiliki kemiripan dengan tulisan ini yakni: Pertama jurnal yang berjudul "Pengaturan Kewenangan Pembuatan Surat Kuasa Membebankan Hak Tanggungan (SKMHT)" oleh Lingga Citra Herawan dari Universitas Surabaya pada tahun 2013 yang meneliti "SKMHT sebagai kuasa khusus. Sesuai dengan ketentuan dalam Pasal 1795 B.W. Dalam hal ini SKMHT merupakan kuasa dari pemberi hak tanggungan. Perjanjian jaminan yang berkolerasi dengan perjanjian kuasa, sebab untuk mendapatkan hak tanggungan haruslah membuat suatu akta otentik berupa Akta Pemberian Hak Tanggungan, dimana suatu APHT didahului dengan SKMHT. Pembuatan SKMHT ditentukan dalam Pasal 15 ayat (1) UUHT yaitu 
dibuat oleh PPAT dan atau Notaris. Dapat dilihat terlebih dahulu tentang peraturan jabatan Notaris maupun PPAT. Hasil penelitian ini menunjukan, SKMHT karena merupakan hasil dari Perjanjian Kuasa yang diadakan oleh para pihak dan ini termasuk dalam bidang Hukum Perdata, tidak termasuk bidang Hukum Pertanahan, maka sebenarnya yang berwenang membuat SKMHT adalah Notaris. Sebab berdasarkan ketentuan dalam PP No.37 Tahun 1998, PPAT berwenangnya hanya membuat akta yang berisi peralihan dan pembebanan hak atas tanah. Dekimian juga kalau dicocokkan dengan PP No. 37 Tahun 1998, ternyata dalam pasal-pasalnya kewenangan PPAT sudah ditetakan dan membuat SKMHT tidak tercantum disitu. Berdasarkan hal tersebut maka wewenang sudah sewajarnya kalau SKMHT itu lebih tepat yang membuat aktanya adalah Notaris". ${ }^{7}$ Kedua jurnal yang berjudul "Fungsi Dan Kedudukan Surat Kuasa Membebankan Hak Tanggungan Yang Dibuat Oleh Notaris" oleh Mieke Aprilia Utami, Amelia Rachman, Riaddah dari Sekolah Tinggi Ilmu Hukum Kuala Kapuas pada tahun 2020 yang meneliti "mengenai apakah kajian yuridis terhadap pembuatan surat kuasa membebankan hak tanggungan menurut Undang-Undang Hak Tanggungan dan apa tanggung jawab notaris terhadap dibuatnya surat kuasa membebankan hak tanggungan berdasarkan ketentuan yang berlaku. Hasil Penelitian menunjukan bahwa fungsi SKMHT yang dibuat Notaris adalah untuk menjamin kepastian hukum dan perlindungan hukum bagi kreditur selaku pemegang Hak Tanggungan dan debitur selaku pemberi Hak Tanggungan. Untuk terciptanya tertib administrasi dalam proses pendaftaran Hak Tanggungan kepada Kantor Pertanahan sebagai Lembaga pendaftaran. Kedudukan SKMHT adalah sebagai alat bukti yang sempurna dalam bentuk akta otentik yang dibuat oleh Notaris. Pertanggungjawaban Notaris dapat dilihat dari jenis akta yang dibuat Ambtelijk akta maupun Partij Akta. Notaris bertanggung jawab secara perdata atas akta yang dibuatnya (Essensi akta). Notaris pun dapat dituntut pidana apabila terjadi pemalsuan dan pengelapan atas akta yang dibuatnya." ${ }^{8}$ Ketiga jurnal yang berjudul "Surat Kuasa Membebankan Hak Tanggungan (SKMHT) Dan Pengaruhnya Terhadap Pemenuhan Azas Publisitas Dalam Proses Pemberian Hak Tanggungan" oleh Made Oka Cahyadi Wiguna, Universitas Pendidikan Nasional Denpasar 2015 yang meneliti "tinjauan yuridis SKMHT dalam akta otentik yang dibuat oleh Notaris serta pengaruh SKMHT dalam pemenuhan asas publisitas hak tanggungan. Hasil Penelitian menunjukan daam ketentuan UUHT mengatur, bahwa SKMHT dibuat dengan akta notaris atau akta PPAT. Berdasarkan ketentuan tersebut dapat ditafsirkan bahwa, SKMHT harus dibuat dalam bentuk akta otentik. Notaris dan PPAT adalah pejabat umum mempunyai kewenangan untuk membuat akta otentik berdasarkan UUJN dan Peraturan Pemerintah tentang PPAT.SKMHT wajib dibuat dengan mengikuti bentuk akta berdasarkan UUJN. Sekalipun SKMHT dibuat oleh Notaris, namun apabila bentuknya tidak memenuhi ketentuan UUJN, maka SKMHT tersebut hanya mempunyai kekuatan pembuktian sebagai akta di bawah tangan. Apabila SKMHT tersebut tetap digunakan sebagai dasar dalam pembuatan APHT, maka sesungguhnya

\footnotetext{
${ }^{7}$ Herawan, L. C. (2013). Pengaturan Kewenangan Pembuatan Surat Kuasa Membebankan Hak Tanggungan (SKMHT). CALYPTRA, 2(2), h.2.

8 Utami, M. A., \& Rachman, A. (2020). Fungsi Dan KedudukanSurat Kuasa Membebankan Hak Tanggungan Yang Di Buat Oleh Notaris. Jurnal Sagacious, 6(2), h.5.
} 
APHT yang dibuat juga tidak mempunyai kekuatan hukum sehingga publisitas dari pembebanan Hak Tanggungan tidak dapat terpenuhi." ${ }^{9}$

Tulisan pertama dan kedua di atas memiliki pokok permasalahan yang berbeda dengan tulisan ini, sedangkan pada tulisan ketiga hampir sama dengan tulisan ini. Perbedaanya dimana tulisan ini memfokuskan pada membandingkan surat kuasa membebankan hak tanggungan (SKMHT) berdasarkan UUJN dengan PERKABAN No.8 Th 2012. Membahas juga tentang kepastian hukum surat kuasa membebakan hak tanggungan (SKMHT) yang dibuat dihadapan Notaris dengan mengikuti format PERKABAN Nomor 8 Tahun 2012.

\section{Metode Penelitian}

Penelitian ini adalah penelitian hukum normatif dengan pendekatan peraturan perundang-undangan yang berlaku, dan penelitian ini menggunakan bola salju sebagai mengumpulkan bahan hukumnya. Bahan Hukum yang digunakan yakni undangundang dan Peraturan Menteri sebagai bahan hukum primer dan bahan hukum sekunder berupa jurnal dan buku yang terkait dengan jurnal ini. Teknik analisa yang digunakan yakni teknik deskriptif dan teknik argumentatif. Penelitian ini disebut penelitian hukum normatif karena terdapat konflik norma dan disini penulis menguraikan tentang perbandingan SKMHT yang dibuat oleh Notaris yang tunduk pada UUJN dan SKMHT yang dibuat oleh PPAT yang tunduk pada Peraturan Kepala Badan Pertanahan No.8 Tahun 2012 (selanjutnya disebut PERKABAN No.8 Th 2012).

\section{Hasil Dan Pembahasan}

\subsection{Perbandingan Akta Autentik Menurut UUJN dan PERKABAN No.8 Th 2012 Dalam Pembuatan SKMHT}

Notaris adalah pejabat umum dengan kewenangan membuat akta autentik. ${ }^{10}$ Dalam pembuatan akta autentik kewenangan yang diberikan terhadap Notaris diatur dalam Pasal 1 (1) UUJN yang berbunyi: "Notaris adalah pejabat umum yang berwenang untuk membuat akta autentik dan kewenangan lainnya sebagaimana dimaksud dalam Undang-Undang ini."

Akta Notaris memiliki makna yang diatur dalam Pasal 1 (7) UUJN yang berbunyi: "Akta Notaris adalah akta autentik yang dibuat oleh atau di hadapan Notaris menurut bentuk dan tata cara yang ditetapkan dalam Undang-Undang ini." Dapat dipahami bahwa agar menjadi sebagai akta yang tidak membutuhkan pembuktian maka harus dibuat sesuai dengan aturan dalam undang-undang. Akta autentik dan surat dibawah tangan memiliki perbedaan yang sangat jelas, surat dibawah tangan kekuatan pembuktiannya hanya antara para pihak yang melakukan perjanjian saja, perbedaan

${ }^{9}$ Wiguna, M. O. C. (2018). Surat Kuasa Membebankan Hak Tanggungan (SKMHT) Dan Pengaruhnya Terhadap Pemenuhan Azas Publisitas Dalam Proses Pemberian Hak Tanggungan, Power Of Attorney Imposing Security Rights And Its Influence To Publicity Rights Fullfilment In Security Rights Providing. Jurnal Legislasi Indonesia, 12(2), h.5.

10 Pramono, D. (2015). Kekuatan pembuktian akta yang dibuat oleh notaris selaku pejabat umum menurut hukum acara perdata di Indonesia. Lex Jurnalica, 12(3), 147736, h.249. 
juga terdapat dalam pasal 15 UUJN,11 "menjamin kepastian tanggalnya dan...." Akta autentik mempunyai tanggal yang pasti sedagkan surat bawah tangan tidak demikian.

Menurut Sudikno Mertokusumo, "Akta merupakan surat yang diberi tanda tangan yang memuat peristiwa-peristiwa yang menjadi dasar suatu hak atau perikatan, yang dibuat sejak semula dengan sengaja untuk pembuktian."12 Atas gagasan yang disampaikan, maka kesimpulannya yakni perbuatan hukum dan tulisan yang dibuat dan dipergunakan sebagai alat untuk menemukan membuktian. ${ }^{13}$

Pada PasaI 165 Staatsblad Tahun 1941 No.84 memberikan penjelasan, yaitu sebagai berikut:

\begin{abstract}
"Akta adalah surat yang diperbuat demikian oleh atau dihadapan pegawai yang berwenang untuk membuatnya menjadi bukti yang cukup bagi kedua belah pihak dan ahli warisnya maupun berkaitan dengan pihak lainnya sebagai hubungan hukum, tentang segala hal yang disebut didalam surat itu sebagai pemberitahuan hubungan langsung dengan perihal pada akta itu."
\end{abstract}

Pasal 1868 KUHPer, juga menjelaskan suatu akta autentik ialah "suatu akta yang didalam bentuk yang ditentukan oleh undang-undang, dibuat oleh atau dihadapan pegawai-pegawai umum yang berkuasa untuk itu ditempat dimana akta dibuatnya." Menurut Irwan Soerodjo, bahwa untuk dapat dikatakan akta autentik terdapat 3 hal penting syarat formil yakni “(1) di dalam bentuk yang ditentukan oleh undangundang; (2) dibuat oleh dan di hadapan Pejabat Umum; (3) akta yang dibuat oleh atau di hadapan Pejabat Umum yang berwenang untuk itu dan di tempat dimana akta itu dibuat."14

Pembebanan HT memang harus dilakukan oleh yang bersangkutan tetapi dapat juga dikuasakan apabila benar-benar diharuskan untuk membuat kuasa hal ini di atur dalam UUHT. Ketentuan Pasal 15 UUHT menentukan "Surat Kuasa Membebankan Hak Tanggungan (SKMHT) wajib dituangkan dalam bentuk akta Notaris atau akta Pejabat Pembuat Akta Tanah." Frasa "wajib dibuat dengan akta Notaris dan PPAT" dalam Pasal 15 UUHT, maka SKMHT tersebut harus dibuat dengan akta autentik tentunya oleh pejabat umum yang memiliki kewenangan untuk itu.

SKMHT dalam pembuatannya, seorang PPAT tunduk pada tata cara pengisian SKMHT sebagaimana diatur Pada Pasal 96 ayat (1) huruf f PERKABAN No.8 Th.2012, sedangkan Notaris harus patuh pada UUJN. UUJN adalah aturan yang mengikat seorang Notaris. Pada kenyataan dalam menjalankan jabatannya, Notaris yang merangkap sebagai PPAT terikat pada dua aturan yang berbeda, disatu sisi dalam pembuatan SKMHT, Notaris harus tunduk dengan aturan yang telah ditetapkan oleh UUJN mengenai format dan bentuknya, namun di sisi lain merangkap sebagai PPAT, maka format SKMHT harus tunduk kepada PERKABAN No.8 Th.2012 yang dikeluarkan oleh BPN-RI.

${ }^{11}$ Palit, R. C. (2015). Kekuatan Akta di Bawah Tangan Sebagai Alat Bukti di Pengadilan. Lex Privatum, 3(2), h.137.

12 Mertokusumo, Sudikno., 2006, Hukum Acara Perdata Indonesia. Liberty, Yogyakarta, h.149

${ }^{13}$ Siahaan, K. (2019). Kedudukan Hukum Akta NotarisSebagai Alat Bukti Pada Tindak Pidana

Pemalsuan Surat Dalam Proses Peradilan Pidana. Recital Review, 1(2), h.38.

${ }^{14}$ Soerodjo, Irwan., 2003, Kepastian Hukum Hak Atas Tanah di Indonesia. Arkola, Surabaya, h.148 
Berdasarkan Pasal 16 UUJN “Dalam menjalankan jabatannya, Notaris berkewajiban: (a) bertindak jujur, saksama, mandiri, tidak berpihak, dan menjaga kepentingan pihak yang terkait dalam perbuatan hukum." Seksama dimaksud, bahwa dalam membuat akta autentik adalah notaris harus menjaga kepentingan para pihak sehingga akta autentik ini bisa memberi perlindungan hukum terhadap kepentingan mereka.

Tabel Pembanding SKMHT Berdasarkan Pasal 96 (1) huruf h Perkaban 8 Tahun 2012 Dengan UUJN

\begin{tabular}{|c|c|c|}
\hline $\begin{array}{c}\text { Pem } \\
\text { banding }\end{array}$ & $\begin{array}{c}\text { SKMHT Menurut UUJN, } \\
\text { Pasal } 38 \text { (2) }\end{array}$ & $\begin{array}{l}\text { SKMHT Menurut Perkaban No. } \\
8 \text { Th. } 2012\end{array}$ \\
\hline $\begin{array}{l}\text { Kepala } \\
\text { Akta }\end{array}$ & $\begin{array}{l}\text { judul akta; Nomor akta; Jam, hari, } \\
\text { tanggal, bulan, dan tahun; dan Nama } \\
\text { lengkap dan tempat kedudukan } \\
\text { Notaris. }\end{array}$ & $\begin{array}{l}\text { judul Akta; Nomor akta; Hari, } \\
\text { Tanggal, Bulan, Tahun; Nama } \\
\text { lengkap, Tanggal Dan Nomor } \\
\text { Surat Keputusan Pengangkatan, } \\
\text { Daerah Kerja dan Alamat Kantor }\end{array}$ \\
\hline $\begin{array}{c}\text { Badan } \\
\text { Akta }\end{array}$ & $\begin{array}{l}\text { 1.nama lengkap, tempat dan tanggal } \\
\text { lahir, kewarganegaraan, pekerjaan, } \\
\text { jabatan, kedudukan, tempat tinggal } \\
\text { para penghadap dan/atau orang } \\
\text { yang mereka wakili; } \\
\text { 2. keterangan mengenai kedudukan } \\
\text { bertindak penghadap; } \\
\text { 3.isi akta yang merupakan kehendak } \\
\text { dan keinginan dari pihak yang } \\
\text { berkepentingan; } \\
\text { 4.nama lengkap, tempat dan tanggal } \\
\text { lahir, serta pekerjaan, jabatan, } \\
\text { kedudukan, tiap saksi pengenal. }\end{array}$ & $\begin{array}{l}\text { 1. komparisi para pihak. } \\
\text { 2. pengenalan penghadap atau } \\
\text { adanya saksi pengenal. } \\
\text { 3. isi akta. }\end{array}$ \\
\hline $\begin{array}{l}\text { Akhir } \\
\text { Akta }\end{array}$ & $\begin{array}{l}\text { 1. pembacaan akta sebagaimana } \\
\text { dimaksud dalam Pasal } 16 \text { ayat (1) } \\
\text { huruf I atau Pasal } 16 \text { ayat (7); } \\
\text { 2.penandatanganan dan tempat } \\
\text { penandatanganan atau } \\
\text { penerjemahan akta apabila ada; } \\
\text { 3.nama lengkap, tempat dan tanggal } \\
\text { lahir, pekerjaan, jabatan, } \\
\text { kedudukan, dan tempat tinggal } \\
\text { 4.dari tiap-tiap saksi akta; dan } \\
\text { 5.tidak adanya perubahan yang } \\
\text { terjadi dalam pembuatan akta atau }\end{array}$ & $\begin{array}{l}\text { 1. mengenai saksi-saksi akta. } \\
\text { 2.pembacaan dan penjelasan } \\
\text { akta. } \\
\text { 3.penandatanganan akta. } \\
\text { 4.jumlah rangkap SKMHT. }\end{array}$ \\
\hline
\end{tabular}




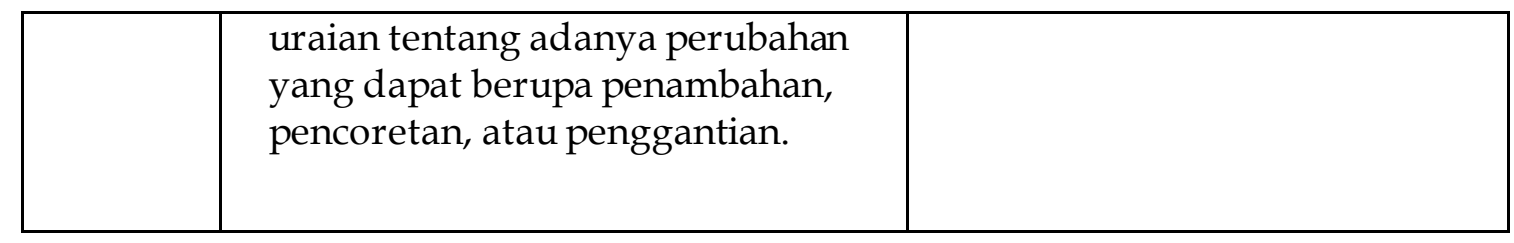

Tabel di atas dari awal akta saja sudah dapat diketahui bahwa adanya perbedaan antara SKMHT Notaris dan SKMHT yang dikeluarkan oleh BPN-RI. Pada SKMHT yang dikeluarkan oleh BPN tidak ada informasi yang menunjukkan kapan SKMHT itu dibuat, sedangkan pada SKMHT Notaris, tanggal pembuatan akta adalah suatu keharusan. Selanjutnya menurut PMNA/KaBPN No.3/1997 "Notaris tidak perlu mengisi daerah kerjanya", hal ini tentunya bertentangan dengan Pasal 38 (2) UUJN, dimana dalam akta Notaris harus menegaskan wilayah kerja Notaris. Keterangan yang menunjukan wilayah kerja Notaris sangat penting sebagaimana yang ditetapkan dalam Pasal 1868 KUHPerdata adalah "pejabat tersebut berwenang di tempat di mana akta tersebut dibuat."

Tempat kedudukan notaris sangat penting karena sebagai bukti dari kewenangan bertindak seorang Notaris. Jika dilihat dari SKMHT yang dikeluarkan oleh BPN-RI pada badan akta tidak bertentangan dengan Pasal 38 UUJN, hanya saja pada pengisian komparisi pada blanko yang diterbitkan BPN-RI harus memuat seperti yang ada pada pasal 38 UUJN. Notaris dalam membuat akta autentik harus memuat identitas para penghadap. Terakhir pada akhir akta dari SKMHT yang dikeluarkan BPN-RI dimana tidak adanya informasi yang memuat mengenai tempat penandatanganan akta.

Notaris adalah pejabat umum yang berkerja dengan memiliki kewenangan terbatas atas tempat kedudukan jabatan, sehingga seorang Notaris hanya bisa membuat akta sesuai dengan tempat kedudukannya dimana dalam akta Notaris dijelaskan pada awal akta dan akhir akta. Jika Notaris membuat akta autentik diluar kedudukan jabatanya maka akta tersebut akan terdegradasi menjadi akta dibawah tangan. Selanjutnya berdasarkan Pasal 50 (4) UUJN, "Pada penutup setiap akta dinyatakan jumlah perubahan berupa, pencoretan, pencoretan dengan penggantian dan penambahan." Untuk itu pada setiap akhir akta, jika terdapat perubahan, coretan dan penggantian, maka pada akhir akta harus dinyatakan dengan tegas berapa jumlah perubahan, coretan dan penggantian tersebut.

Berdasarkan penjelasan tersebut diatas, dimana terdapat perbedaan antara SKMHT berdasarkan ketentuan UUJN dan SKMHT yang dikeluarkan oleh BPN, maka ketika Notaris akan mengsi akta SKMHT yang dikeluarkan oleh BPN-RI, maka haruslah menambahkan tempat kedudukan jabatanya, tempat penandatanganan akta dan juga harus menguraikan dengan tegas mengenai berapa jumlah perubahan, coretan dan penggantian jika ada, tujuannya agar otentisitas dari akta tersebut dapat dijaga.

Blanko SKMHT yang diterbitkan oleh BPN-RI, pada bagian akhir disebutkan dibuat in-originali dan dibuat 2 lembar, dimana 1 lembar disimpan di kantor PPAT dan yang 1 lagi diserahkan kepada penerima kuasa. UUJN menjelaskan bahwa akta in-originali adalah akta yang tidak ada minutanya, tetapi akta asli tersebut langsung diserahkan 
kepada yang berkepentingan. ${ }^{15}$ Blanko SKMHT yang diterbitkan BPN-RI berbeda dan tidak sesuai dengan ketentuan yang telah ditetapkan dalam UUJN. Akta yang dikeluarkan oleh Notaris harus dibuat dengan berdasarkan aturan dalam Pasa1 38 UUJN, agar keautentikannya tetap terjaga. Blanko yang diterbitkan oleh BPN RI tidak sesuia dengan akta autentik yang seharusnya dibuat oleh Notaris, sehingga perlu dilakukannya penyelarasan dengan cara menambahkan hal-hal yang kurang pada blanko BPN-RI agar menjadi akta notariil.

\subsection{Kepastian Hukum Surat Kuasa Membebakan Hak Tanggungan (SKMHT) Yang Dibuat Dihadapan Notaris Dengan Mengikuti Format Perkaban Nomor 8 Tahun 2012}

Pemasangan pembebanan HT, wajib dihadiri langsung oleh pihak pemberi HT sebagai yang berhak dalam melakukan perbuatan hukum yang berhubungan dengan pemasangan HT, tetapi jika pemberi HT berhalangan hadir dihadapan pejabat yang berwenang, maka akan dibuat surat kuasa yang biasa disebut dengan SKMHT. Menurut Pasal 15 (1) UUHT: "Surat Kuasa Membebankan Hak Tanggungan wajib dibuat dengan akta Notaris atau akta Pejabat Pembuat Akta Tanah." Berdasarkan ketentuan tersebut, maka fungsi SKMHT adalah sebagai solusi apabila pemberi HT berhalangan hadir untuk menghadap PPAT. ${ }^{16}$

Berdasarkan Pasal 15 UUHT, SKMHT dibuat harus dengan akta autentik sehingga dapat dibuat oleh notaris atau PPAT. Keabsahan suatu SKMHT menurut Pasal 15 ayat

(1) UUHT adalah:

1) "Tidak memuat kuasa untuk melakukan perbuatan hukum lain daripada membebankan Hak Tanggungan." Menurut ketentuan tersebut, maka SKMHT harus dibuat terpisah dengan perjanjian-perjanjian lainnya misal dengan perjanjian kredit.

2) "Tidak memuat hak substitusi", namun dengan berlakunya Pasal 1803 ayat (2) KUHPerdata, maka hak subsitusi dapat dicantumkan apabila objek HT berada diluar daerah si pemberi HT.

3) "Mencantumkan secara jelas objek HT, jumlah utang, dan nama serta identitas kreditornya, nama dan identitas debitor apabila debitor bukan pemberi HT." Tujuannya agar tidak dapat dipergunakan untuk kepentingan lainnya.

Pasal 15 ayat (3) UUHT, menetukan "SKMHT yang sudah terdaftar wajib diikuti dengan pembuatan APHT selambat-lambatnya 1 (satu) bulan sesudah diberikan." Selanjutnya pada Pasal 15 ayat (4) UUHT, menentukan "mengenai hak atas tanah yang belum terdaftar wajib diikuti dengan pembuatan APHT selambat-lambatnya 3 (tiga) bulan setelah diberikan."

Berdasarkan hasil penelitian bahwa blanko SKMHT yang dikeluarkan oleh BPN-RI

${ }^{15}$ J.Satrio. (1998) Hukum Jaminan, Hak Jaminan, Kebendaan, Hak Tanggungan Buku 2. Bandung: Citra Aditya Bakti. h.203-204

16 Silviana, A. (2020). Fungsi Pemasangan Surat Kuasa Membebankan Hak Tanggungan (SKMHT) Dalam Pemberian Hak Tanggungan (Studi Perspektif UU No. 4 Tahun 1996 Tentang Hak Tanggungan Beserta Benda-Benda Yang Berkaitan Dengan Tanah). Diponegoro Private Law Review, 7(1), h.676. 
tidak sesuai dengan keautentikan suatu akta sebagaimana ditentukan dalam Pasal 38 UUJN, sehinga SKMHT yang di keluarkan oleh BPN-RI tidak dapat dikategorikan sebagai akta autentik yang memiliki kekuatan pembuktian sempurna. Syarat akta autentik seorang Notaris sesuai dengan UUJN dan apabila tidak sesuai maka akta tersebut berkedudukan sebagai surat dibawah tangan saja. ${ }^{17}$ Karena akta SKMHT yang diterbitkan BPN-RI tidak memenuhi aturan UUJN, berarti tidak dapat dijadikan sebagai alat pembuktian sempurna kecuali pada akta tersebut dilakukan penambahan seperti yang disampaikan di atas.

Berdasarkan Pasal 15 (1) UUHT bahwa "SKMHT wajib dibuat dalam akta Notaris atau PPAT". Pasal 1 ayat (7) UUJN, menentukan bahwa "Akta Notaris yang selanjutnya disebut Akta adalah akta autentik yang dibuat oleh atau di hadapan Notaris menurut bentuk dan tata cara yang ditetapkan dalam Undang-Undang ini." SKMHT yang dibuat oleh Notaris dengan mengikuti ketentuan PERKABAN No.8 Th.2012, tidak dapat dijadikan dasar dari pembuatan APHT", dikarenakan terdapat perbedaan format antara SKMHT yang dikeluarkan oleh Notaris dan SKMHT yang dikeluarkan PPAT. Perbedaan ini tentu saja menimbulkan akibat hukum terkait keabsahan SKMHT tersebut sebagai dasar pembuatan APHT, karena SKMHT tersebut tidak dapat dikategorikan sebagai akta autentik. Akibat hukum dari akta Notaris yang tidak dikategorikan sebagai akta autentik adalah akta akan menjadi akta dibawahtangan dan tidak dapat digunakan sebagai alat pembuktian yang sempurna, sehingga akta tersebut tidak dapat memberikan kepastian hukum terhadap para pihak yang membuatnya.

\section{Kesimpulan}

Hasil penelitian ini menunjukan bahwa perbandingan akta autentik menurut UUJN dan Perkaban No.8 Th 2012 mengenai pembuatan SKMHT yang dibuat dihadapan Notaris terdapat perbedaan pada bagian kepala dan akhir akta. Blanko SKMHT yang diterbitkan BPN-RI berbeda dan tidak sesuai dengan ketentuan yang telah ditetapkan dalam UUJN. Akta yang dibuat oleh Notaris harus dibuat berdasarkan aturan dalam Pasa1 38 UUJN, agar keautentikannya tetap terjaga. Kedua, kepastian hukum SKMHT yang dibuat oleh Notaris dengan mengikuti format Perkaban No.8 Th.2012, akta tersebut tidak dapat memberikan kepastian hukum. Akta tersebut akan terdegradasi menjadi surat dibawahtangan, sehingga SKMHT tidak bisa dijadikan dasar dalam pembuatan APHT, untuk mengatasi hal tersebut Notaris diberikan hak untuk menambahkan kekurangan pada blangko tersebut agar tetap menjadi akta autentik.

\section{Daftar Pustaka}

\section{$\underline{\text { Buku }}$}

17 Sasauw, C. (2015). Tinjauan Yuridis Tentang Kekuatan Mengikat Suatu Akta Notaris. Lex Privatum, 3(1). h.98. 
J.Satrio., 1998, Hukum Jaminan, Hak Jaimnan, Kebendaan, Hak Tanggungan, Buku 2, Citra Aditya Bakti, Bandung.

Simorangkir, O.P., 1998, Seluk Beluk Bank Komersial, Persada Indonesia, Jakarta.

Soerodjo, Irwan., 2003, Kepastian Hukum Hak Atas Tanah di Indonesia, Arkola, Surabaya.

\section{Jurnal}

Herawan, L. C. (2013). Pengaturan Kewenangan Pembuatan Surat Kuasa Membebankan Hak Tanggungan (SKMHT). CALYPTRA, 2(2),1-10.

Setiono, G. C. (2018). Jaminan kebendaan dalam proses perjanjian kredit perbankan (tinjauan yuridis terhadap jaminan benda bergerak tidak berwujud). Transparansi Hukum, 1(1). h.7. DOI: http://dx.doi.org/10.30737/transph.v1i1.159

Pakel, Y. (2018). Kedudukan Bank Sebagai Kreditor Separatis Dalam Pengurusan Dan Pemberesan Harta Pailit. Al-Amwal: Journal ofilslamic Economic Law, 3(1),61-82. DOI: https://doi.org/10.24256/alw.v3i1.200

Palit, R. C. (2015). Kekuatan Akta di Bawah Tangan Sebagai Alat Bukti di Pengadilan. Lex Privatum, I3(2).

Pramono, I D. (2015). Kekuatan pembuktian akta yang dibuat oleh notaris selaku pejabat umum menurut hukum acara perdata di Indonesia. Lex Jurnalica, 12(3), 147736.

Rusdianto, H., \& Ibrahim, C. (2016). Pengaruh Produk Bank Syariah Terhadap Minat Menabung Dengan Persepsi MasyarakatSebagai Variabel Moderating Di Pati. Equilibrium: Jumal Ekonomi Syariah, 4(1), 43-61. DOI: 10.21043/equilibrium.v4i1.1837

Sasauw, C. (2015). Tinjauan Yuridis Tentang Kekuatan Mengikat Suatu Akta Notaris. Lex Privatum, 3(1).

Siahaan, K. (2019). Kedudukan Hukum Akta Notaris Sebagai Alat Bukti Pada Tindak Pidana Pemalsuan Surat Dalam Proses Peradilan Pidana. Recital Review, 1(2), 72-88.

Silviana, A. (2020). Fungsi Pemasangan Surat Kuasa Membebankan Hak Tanggungan (SKMHT) Dalam Pemberian Hak Tanggungan (Studi Perspektif UU No. 4 Tahun 1996 Tentang Hak Tanggungan Beserta Benda-Benda Yang Berkaitan Dengan Tanah). Diponegoro Private Law Review, 7(1),28-39.

Tambunan, M. R., \& Nasution, I. G. S. (2013). Analisis faktor-faktor yang mempengaruhi keputusan nasabah menabung di Bank BCA kota Medan (Studi kasus etnis Cina). Jurnal Ekonomi dan Keuangan, 1(3), 14727. 
Utami, M. A., \& Rachman, A. (2020). Fungsi Dan Kedudukan Surat Kuasa Membebankan Hak Tanggungan Yang Di buat Oleh Notaris. Jurnal Sagacious, $6(2), 1-14$.

Wiguna, M. O. C. (2018). Surat Kuasa Membebankan Hak Tanggungan (SKMHT) Dan Pengaruhnya Terhadap Pemenuhan Azas Publisitas Dalam Proses Pemberian Hak Tanggungan, Power Of Attorney Imposing Security Rights And Its Influence To Publicity Rights Fullfilment In Security Rights Providing. Jurnal Legislasi Indonesia, 12(2).

Yusuf, Rifki \& Maryanto. (2018). Peran Notaris Dalam Penggunaan Akta SKMHT Yang Tidak Diikuti APHT Terhadap Debitor Wanprestasi Terkait Pemberian Fasilitas Kredit Pemilikan Rumah Subsidi (Studi Kasus di Bank Tabungan Negara Pekalongan). Jurnal Akta, 5(1),275-287.

\section{Peraturan Perundang-undangan}

Kitab Undang-Undang Hukum Perdata (Staatsblad Tahun 1847 Nomor 23) Terjemahan R. Subekti dan R. Tjitrosudibio, 2003, PT. Pradnya Paramitha.

Negara Republik Indonesia, Undang-Undang Nomor 4 Tahun 1996 tentang Hak Tanggungan Atas Tanah Beserta Benda - Benda Yang Berkaitan Dengan Tanah (Lembaran Negara Republik Indonesia Tahun 1996 Nomor 42, Tambahan Lembaran Negara Nomor 3632).

Negara Republik Indonesia, Undang-Undang Nomor 2 Tahun 2014 tentang Perubahan atas Undang-Undang Nomor 30 Tahun 2004 tentang Jabatan Notaris, Lembaran Negara Republik Indonesia Tahun 2014 Nomor 3, Tambahan Lembaran Negara Republik Indonesia Nomor 5491.

Negara Republik Indonesia, Undang-Undang Nomor 10 Tahun 1998 tentang Perubahan atas Undang-Undang Nomor 7 Tahun 1992 tentang Perbankan, Lembaran Negara Republik Indonesia Tahun 1998 Nomor 182, Tambahan Lembaran Negara Republik Indonesia Nomor 3790.

Peraturan Kepala Badan Pertanahan Nasional Republik Indonesia Nomor 8 Tahun 2012 Tentang Perubahan Atas Peraturan Mentri Negara Agraria/ Kepala Badan Pertanahan Nasional Republik Indonesia Nomor 3 Tahun 1997 Tentang Ketentuan Pelaksanaan Peraturan Pemerintah Nomor 24 Tahun 1997 Tentang Pendaftaran Tanah 